\title{
RUANG PEMBERDAYAAN KAUM IBU MUARA ANGKE SEBAGAI TEMPAT KETIGA
}

\author{
Joshua Ervin Novaldi ${ }^{1}$, Doddy Yuono ${ }^{2)}$ \\ 1)Program Studi S1 Arsitektur, Fakultas Teknik, Universitas Tarumanagara, Joshuaervinnovaldi@gmail.com \\ 2)Program Studi S1 Arsitektur, Fakultas Teknik, Universitas Tarumanagara, Doddyy@ft.untar.ac.id
}

Masuk: 15-07-2020, revisi: 01-08-2020, diterima untuk diterbitkan: 24-09-2020

\begin{abstract}
Abstrak
Jakarta sebagai ibu kota negara selama bertahun-tahun banyak mengalami perubahan. Setiap perubahan dipengaruhi oleh masalah yang ada di setiap wilayahnya. Hal ini memunculkan keunikan setiap wilayah dengan penyelesaian masalah yang berbeda-beda. Keunikan ini menjadikan setiap wilayah mempunyai sektor masing-masing seperti wilayah perkantoran, perumahan, industri, dan lain-lain. Walaupun banyak sektor di Jakarta dengan fungsi yang sama, masalah yang terjadi belum tentu sama, bergantung kepada masyarakat di dalamnya. Ditambah dengan persebaran penduduk datang dan pergi Jakarta yang terbilang cukup besar, menambah variabel dari setiap masalah wilayah yang diselesaikan. Muara Angke, Penjaringan, Pluit merupakan wilayah industri perikanan dan perumahan yang didatangi banyak pengunjung perharinya. Mayoritas nelayan, akan tetapi perkembangan zaman merubah pekerjaan nelayan dan beralih ke pekerja kantoran, namun pekerjaanan ini menjadi hal sulit, mengingat tingkat pendidikan di Muara Angke terbilang rendah. Tujuan utama dari penyelesaian masalah setiap wilayah adalah untuk peningkatan pendapatan masyarakatnya. Muara Angke dengan industri perikanan dan hasil lautnya belum maksimal untuk membuat masyarakatnya hidup sejahtera karena masih banyak nelayan yang bergantung kepada penyewa kapal yang membuat pendapatan mereka berkurang. Pemberdayaan kaum ibu di Muara Angke bisa memaksimalkan sumber daya alam yang didapat. Penempatan kaum ibu menjadi titik tengah dari penyelesaian masalah Muara Angke melalui ruang ketiga, diharapkan dapat mendongkrak kualitas hidup masyarakat dengan adanya area berkumpul dan bekerja. Pembentukan ruang ketiga ini didukung dan didasarkan oleh undang-undang PermenKP nomor 28 tahun 2016, PermenKP nomor 51 tahun 2016, KepmenKP nomor 67 tahun 2016 yang berisikan tentang kegiatan responsif gender.
\end{abstract}

\section{Kata kunci: Gender; Hasil Laut; Kualitas Hidup; Ruang Publik}

\begin{abstract}
Jakarta as the capital of the country has changed for many years. Every change that occurs is influenced by problems that are in each region. This unites the uniqueness of each region by solving different problems. From this uniqueness, it makes every region in Jakarta has its sector, such as offices, housing, industry, and others. Although there are many sectors in Jakarta with the same function, the problems that occur are not necessarily the same that depends on the people in them. Coupled with the distribution of people coming and going to Jakarta which is quite large, adding to the variable of each problem area is solved. The Muara Angke region, Penjaringan, Pluit is a fishing and housing industry area that is visited by many visitors a day. The majority of the Muara Angke community are fishermen, but because of the times, many have left the fishing work and turned to office workers. With the level of which is relatively low, office work is difficult. The main objective of solving problems in each region is to increase the income of the community. Muara Angke with its fishing and marine products industry has not been maximized to make its people prosperous because there are still many fishermen who depend on boat charterers who make their income reduced. From the results of studies of empowerment of mothers in Muara Angke can maximize the natural resources obtained from the community. Placement of mothers becomes the midpoint of solving the Muara Angke problem through the third room is expected to be able to boost the quality of life of the people of Muara Angke with the area of gathering and working. The establishment of this third space is supported and based on PermenKP law number 28 in 2016, PermenKP number 51 in 2016, KepmenKP number 67 in 2016 which contains gender-responsive activities.
\end{abstract}

Keywords: Gender; Life Quality; Public Space; Sea Resources 


\section{PENDAHULUAN}

\section{Latar Belakang}

Muara Angke adalah salah satu pelabuhan kapal ikan atau nelayan di Jakarta. Ditandai dengan dioperasikannya penunjang kebutuhan nelayan seperti pelelangan ikan (struktur dan fasilitasnya). Fasilitas Pokok Pelabuhan terdiri dari alur pelayaran (sebagai 'jalan' kapal sehingga dapat memasuki daerah pelabuhan dengan aman dan lancar), penahan gelombang (breakwater untuk melindungi daerah pedalaman pelabuhan dari gelombang, terbuat dari batu alam, batu buatan dan dinding tegak) kolam pelabuhan (berupa perairan untuk bersandarnya kapal-kapal yang berada di pelabuhan) dan dermaga (sarana dimana kapal kapal bersandar untuk memuat dan menurunkan barang atau untuk mengangkut dan menurunkan penumpang. Karasteristik nelayan secara umum sangat mempengaruhi metode penangkapan yang dilakukan oleh masing masing nelayan. Nelayan di Muara Angke memiliki pola penangkapan yang berbeda dengan nelayan Kamal Muara yang berada dekat dengan Muara Angke. Pola penangkapan ini berkaitan dengan metode penangkapan, alat tangkap yang digunakan serta hubungan sosial ekonomi masyarakat pada kedua lokasi tersebut. Perbedaan tersebut memberikan gambaran yang jelas mengenai model pembangunan masyarakat pada kedua komunitas nelayan tersebut. Contoh (2010) menjelaskan bahwa pembangunan masyarakat perlu dilihat dari beberapa modal komunitas (community capital) yang terdiri dari: (a) Modal Manusia (human capital) berupa kemampuan personal seperti pendidikan, pengetahuan, kesehatan, keahlian dan keadaan terkait lainnya; (b) Modal Sumberdaya Alam (natural capital) seperti perairan laut; (c) Modal Ekonomi Produktif (producedeconomic capital) berupa aset ekonomi dan finansial serta aset lainnya; dan (d) Modal Sosial (sosial capital) berupa norma/nilai (trust, reciprocity, norma sosial lainnya), partisipasi dalam jaringan, pro-activity.(Robin, 2018)

Disarikan dari Robin (2018), Modal manusia (human capital) pada kawasan Muara angke tergolong rendah dengan persentasi $23 \%$ tidak sekolah, $57 \%$ mengenyam pendidikan SD, $14 \%$ SMP dan 3\% SMA SMK, 3\% D3. Tetapi Muara angke memiliki modal sumber daya alam berupa perairan laut yang membuat masyarakat Muara Angke bersandar pada bidang pernelayanan. Adapun bahasan dari sisi pembiayaan dan penjualan nelayan di Muara Angke yaitu sebanyak $60 \%$ Nelayan di Muara Angke dalam melakukan kegiatan penangkapan ikan yang kepemilikan kapal diperoleh dari bos (pengepul), ikan hasil tangkapannya harus dijual kembali ke pengepul tersebut. Begitupun nelayan yang menggunakan kapal milik sendiri serta modal sendiri memiliki ikatan yang kuat dengan pengepul meskipun harga yang diberikan tidak sebesar penjualan di TPI. Pola tersebut biasa dikenal dengan istilah Patron-Klien dimana patron (bos) menyediakan peralatan seperti kapal dan alat tangkap, biaya operasional dan akses pasar. Adapun fakta mengenai jender dalam Muara Angke dimana hal ini menyebabkan perbedaan aktifitas antara kaum laki-laki dan perempuan. Pembagian kerja bedasarkan jenis kelamin merupakan fakta yang selalu ada dalm setiap masyarakat dan sifatnya beragam tergantung pada konteks sosial budaya masyarakat tersebut. Pembagian kerja berdasarkan jenis kelamin menyebabkan terkotak-kotaknya jenis pekerjaan yang harus dikerjakan oleh laki-laki dan perempuan. Sebagian besar laki-laki berlayar sedangkan kaum perempuan yang mayoritas adalah istri nelayan di Muara Angke melakukan pekerjaan ganda. Selain harus melakukan pekerjaan domestik dan mengurus anak para istri nelayan juga membantu pekerjaan suaminya seperti membuat jala mengupas kerang, mengasinkan ikan, menjual ikan dan lain-lain.

Secara umum, perempuan dalam masyarakat pesisir memegang pernanan yang amat penting dalam menjaga kelangsungan hidup rummah tangganya. Selain harus bertanggung jawab terhadap urusan domestik, perempuan (istri) juga harus membantu tugas atau pekerjaan lakilaki (suami) dengan cara terlibat aktif mencari nafkah untuk memenuhi kebutuhan rumah tangga. Dalam kasus perempuan pesisir ini memiliki pernanan penting dalam sebagian besar aktifitas domestik dan perdagangan. Penempatan perempuan sebagai titik berat dalam proyek 
ini berkaitan erat dengan third place itu sendiri, dimana sebuah third place yang berbentuk open space membutuhkan berbagai macam kommunitas di dalamnya sehingga terbentuknya ruang sosial yang terpadu. Ruang sosial disini terbentuk karena berkumpulnya masyarakat di suatu tempat, dengen faktor: umur, jender, pekerjaan, dan lingkungan. Ruang sosial ini membentuk ikatan sosial didalamnya untuk kemajuan komunitas didalamnya Menurut buku Beatriz Colombia, Sexuality and space pada faktor jender wanita akan lebih mudah untuk membentuk ikatan sosial disbanding laki-laki. Ikatan sosial itu akan terjadi bila bersifat terus-menerus dan semakin lama ikatan soal itu terjalin maka akan semakin kuat yang berdampak pada kulaitas komunitas itu sendiri. Muara Angke merupakan pusat kegiatan perikanan terpadu yang terletak di Jakarta dan terdapat berbagai isu yang dapat dikaitkan dengan open architecture as this place.

\section{Rumusan Permasalahan}

Berdasarkan latar belakang proyek ini dapat dirumuskan masalah-masalah yang akan diselesaikan. Salah satunya adalah menentukan fasilitas sosial yang dibutuhkan bagi masyarakat Muara Angke yang mayoritasnya adalah nelayan. Menemukan cara mendongkrak finansial nelayan Muara Angke untuk lepas dari kapitalisme melalui program yang akan dituju. Menjawab dalam program cara kaum ibu Muara Angke mengolah hasil tangkapan lautnya guna membantu finansial mereka. Menentukan cara membuat dan memelihara ikatan sosial yang dibentuk oleh perempuan guna memperpanjang umur dari komunitas tersebut di dalam ruang ketiga.

\section{Tujuan}

Tujuan yang ingin dicapai dalam proyek ini adalah untuk merancang fasilitas yang dibutuhkan oleh masyarakat Muara Angke guna memaksimalkan kemampuan sumber daya laut dan masyarakat Muara Angke. Dengan membuat susunan cara kerja dari setiap fungsi yang berkesinambungan untuk membantu kekuatan finansial nelayan Muara Angke. Memaksimalkan program-program yang ditujukan untuk nelayan Muara Angke agar dapat mengolah hasil tangkapannya di dalam proyek yang akan dibuat. Menjelaskan dan mengaplikasikan peranan penting perempuan dalam perkembangan wilayah pesisir dan juga keterkaitan perempuan dengan third place.

\section{KAJIAN LITERATUR}

\section{Open Architecture (Oldenburg, 1997)}

Open Architecture sebagai third place dapat didefinisikan dengan melihat hal-hal penting yang terkait dengan konteks kebutuhan masyarakat kota dan modernitas yang berorientasi pada teknologi, informasi dan individu. Dalam perancangan arstiektur konteks wilayah dan konteks sosial menjadi tumpuan utama dari pembentukan Open Architecture itu sendiri. Third place menjadi sebuah tempat yang mampu mengakomodir kebutuhan kota secara fleksibel dan juga dinamis menurut perkembangan dan keberagaman masyarakatnya. Open Architecture yang berfungsi sebagai ruang antara, ruang yang bukan tempat tinggal dan bukan tempat kerja. Open Architecture merupakan system yang terbuka dan mampu beradaptasi dengan kepentingan terpilih. Konflik-konflik yang terjadi dari masyarakat kota dapat dipecahan atau dilakukan pendekatan melalui rangkaian pendeketan desain dan juga strategi perancangan.

Open Architecture menjadi kesempatan untuk menciptakan sebuah platform arsitektur yang dapat dikombinasikan dengan berbagai macam keadaan dan kondisi masyarakat dalam hal ini masyarakat perkotaan. Open Architecture sebagai platform dibagi menjadi tiga kategori yaitu Commercial, Hosplitality, dan Entertainment. Commercial disini adalah kategori yang terkait dengan hal jual beli jasa maupun barang. Hospitality disini adalah hal-hal yang terkait dengan penerimaan tamu, pengunjung, dan juga pelayanan terhadap masyarakat. Entertainment terkait dengan ekspresi, karena itu erat kaitannya dengan art dan kultur, selain itu terkadang memiliki 
hubungan dengan edukasi, Ketiga kategori ini dibutuhkan masyarakat terutama masyarakat kota.

\section{Third Place}

Third place menurut embrace the place meriset tentang karakteristiknya sebagai berikut, Third Places represent a personal experience

Orang-orang memiliki berbagai kebutuhan tempat ketiga yang harus dipenuhi. Lebih banyak lebih baik, dan keberagaman bertindak sebagai pengganda yang meningkatkan citra komunitas sebagai yang diinginkan tempat tersebut.

Tempat ketiga bersifat pribadi, tetapi tidak harus berdasarkan individual. Itu adalah pengalaman third place yang dipersonalisasikan, dan yang membutuhkan berbagai macam opsi.

\section{Third Places fulfill an individual need}

Salah satu kebutuhan third place adalah interaksi sosial. Terkadang juga butuh kekreatifan didalamnya. Dengan mengikuti perkembangan jaman, third place akan berevolusi mengikutinya. Perkembangan dan evolusi itu juga akan terjadi dari sisi masyarakat itu sendiri demi kesejahteraan setiap individunya.

Third Places take us away from home and work, yet they are as important as either of those for defining who we are and what we do.

Lebih dari karakteristik lainnya, bagian ini menggambarkan perbedaan dan pentingnya Third place sekarang dibandingkan dengan satu generasi yang lalu. Third place mendefinisikan lingkungannya di jaman dimana itu dibuat.

\section{Third Places are personally functional to us}

Kita membutuhkan pengalaman yang diberikan Third place kepada kita. Seperti kita menikmati kebebasan bersepeda dan hiking, kemungkinan manfaat kebugarannya bagi tubuh kita sebagai hasilnya . Jika kita senang bermain dalam blues band, tempat creative performance adalah sesuatu yang kita butuhkan secara pribadi.

Third Places are there when we need them

A simple statement with huge implications. As schedules become less important and constraining "on demand" third place experiences become proportionally

more important. Pernyataan sederhana dengan implikasi besar. Karena jadwal menjadi kurang penting dan membatasi - pengalaman "on demand" Third place menjadi lebih penting.

\section{Perempuan dan Kegiatan Ekonomi}

(diambil dari: http://repository.usu.ac.id/bitstream/123456789/49701/4/Chapter\%20II.pdf)

Menurut Sunyoto (2008), proses transformasi ekonomi dapat dibagi ke dalam tiga kategori periode perkembangan, yaitu :

a. The Family-Based Economy yaitu rumah tangga yang masih menjadi basis ekonomi. Kegiatan produksi banyak dilakukan di dalam rumah. Wanita (ibu rumah tangga) berada pada posisi yang relatif sentral dalam keluarga karena harus bertanggung jawab atas semua pekerjaan yang ada di dalam rumah. Dengan demikian, wanita mempunyai peran penting dalam proses pengambilan keputusan yang berkaitan dengan urusan rumah tangga.

b. The Family-Wage Economy, yaitu transformasi kegiatan ekonomi ke perdagangan. Pada periode ini, wanita berperan ganda (the development of dual roles) dimana di satu pihak sebagai tenaga kerja yang memperoleh upah dan dilain pihak sebagai ibu rumah tangga.

c. The Family-Consumer Economy, yaitu adanya campur tangan pemerintah dalam sistem upah tenaga kerja. Dalam periode ini, terjadi perubahan teknologi yang cukup pesat dan 
peningkatan produktivitas yang dalam perkembangannya membuat anggota keluarga rumah tangga lebih banyak melakukan fungsi konsumsi dan reproduksi.

Keinginan para wanita untuk dapat meningkatkan taraf hidup dan perbaikan keadaan ekonomi serta keadilan sosial keluarga senantiasa tergambar dari upaya yang selalu mereka lakukan, misalnya dengan bekerja di sektor pertanian atau mencari nafkah untuk menambah penghasilan keluarga. Wanita pada umumnya sangat peka dengan keadaan dan permasalahan yang terjadi dalam keluarga, mereka akan menjadi penengah untuk setiap masalah yang terjadi dalam keluarga mereka, juga tidak akan segan-segan untuk memasuki dunia pekerjaan yang beresiko tinggi apabila keadaan keluarga mereka mengharuskan untuk berbuat demikian (Suardiman, 2001). Bagi wanita peran ganda bukanlah hal yang baru, karena sejak kecil mereka telah dilatih untuk hidup mandiri, belajar menjadi istri, anggota masyarakat, dan juga pencari nafkah. Mereka menyadari sulitnya bertahan hidup. Walaupun wanita bukan pencari nafkah yang utama, namun jika wanita mampu mencari nafkah maka statusnya adalah membantu mencari nafkah (Suardiman, 2001).

Peranan bagi wanita secara keseluruhan dapat dikatakan sebagai sesuatu yang mulia dan dijunjung tinggi, hal ini terlihat pada wanita desa yang senantiasa berusaha untuk memenuhi kebutuhan rumah tangga. Upaya yang mereka lakukan misalnya bekerja di sektor pertanian atau mencari nafkah untuk menambah penghasilan keluarga (Daulay, 2001). Kemiskinan yang melanda suatu keluarga menyebabkan kaum wanita tidak dapat begitu saja menyerahkan kelangsungan hidup keluarga kepada suami mereka. Hal ini sangat berbeda dengan kehidupan wanita dari golongan kaya. Peranan ganda bagi wanita khususnya bagi mereka golongan miskin bukanlah menjadi problematika lagi. Problematik bagi mereka adalah justru bagaimana mereka dapat melestarikan kesempatan mereka untuk tetap dapat berperan ganda, yakni sebagai ibu rumah tangga dan sekaligus bread winer (pencari nafkah) bagi keluarga mereka. Di samping itu masalah lain adalah bagaimana para wanita yang bekerja sebagai bread winer ini dapat memperoleh perlakuan yang sama dengan golongan laki-laki baik dalam hal penggajian maupun pelayanan sosial dari majikan mereka (Soetrisno, 2001).

Berbicara mengenai ekonomi selalu dikaitkan dengan manajemen serta pola pengambilan keputusan dalam keluarga serta upaya pemenuhan ekonomi. Manajemen didalam sebuah keluarga akan melibatkan suami maupun istri sebagai pengendali dalam keluarga. Aktivitas dalam sebuah keluarga tidak akan berjalan lancar tanpa adanya kerja sama diantara anggota keluarga dibawah pimpinan suami selaku pencari nafkah dan bekerja sama dengan istri. Peran perempuan dalam ekonomi nelayan tidak terbatas pada aspek sumbangan tunai saja, tetapi juga pada aspek manajemen dalam keluarga. Didalam sebuah manajemen keuangan ekonomi keluarga nelayan sebahagian besar berada ditangan perempuan atau istri khususnya, dan kemudian suami pada umumnya tidak ikut campur tangan dalam urusan rumah tangga. Nelayan sebagai pemburu ikan dilaut selalu tergantung dari anugrah alam yang kemungkinan besar mengalami banyak rintangan. Banyak tidaknya hasil yang diperoleh sangat tergantung pada kondisi alam (Anonima, 2008).

\section{Kaum Ibu Nelayan Dalam Rumah Tangga \\ Diambil dari Harahap et.al}

Indonesia dewasa ini umumnya orang masih menganggap bahwa tugas kaum wanita sebagai seorang istri juga ibu adalah pertama-tama dalam mengurus rumah tangga dengan sebaikbaiknya. Kelihatannya masih agak janggal bila terdapat wanita yang kurang memahami tata rumah tangga dan mereka hanya duduk bermalas-malasan saja bahkan sekarang kaum ibu dirumah tidak pernah tinggal diam dan selalu aktif (Notopuro, 1983). Dalam mengatur rumah tangga nelayan, sangat memungkinkan pentingnya peran istri terutama dalam pengelolaan 
keuangan rumah tangga. Istri juga berperan dalam proses pengambilan keputusan dalam rumah tangga mengingat para suami telah sibuk mencari nafkah. Istri memiliki peran ganda yaitu sebagai pencari nafkah ketika pendapatan suami tidak cukup untuk mecukupi kebutuhan rumah tangga mereka. Menurut Nursyahbani (1999), wanita didorong untuk berpartisipasi secara aktif di sektor publik, sekaligus tetap harus menjalankan fungsinya sebagai istri dan ibu (Anggita, 2012).

Kaum wanita keluarga nelayan umumnya terlibat dalam aktivitas mencari nafkah untuk keluarganya. Selama ini wanita nelayan bekerja menjadi pengumpul kerang-kerangan, pengolah hasil ikan, pembersih perahu yang baru mendarat, membuat/memperbaiki jaring, pedagang ikan, dan membuka warung. Namun, peran wanita di lingkungan nelayan belum dianggap berarti sebagai penghasil pendapatan keluarga, pun hanya dianggap income tambahan (Anonimb , 2008). Merosotnya pendapatan nelayan berpengaruh pada ekonomi rumah tangga. Para istri nelayan akhirnya menjadi korban. Mereka wara-wiri mencari utang dan menggadaikan barang pada saat dia dan suaminya tidak melaut atau cuma dapat beberapa tangkapan. Pekerjaan andalan mereka hanya melaut sedangkan ketrampilan lainnya tidak bisa. Pekerjaan istri nelayan lainnya adalah mencari pinjaman atau ngebon bila tidak punya uang, terutama pada saat hasil laut sedikit atau bahkan tidak ada sama sekali, baik untuk kebutuhan makan seharihari, pengadaan uang untuk keperluan biaya produksi yang utama, yakni perbaikan perahu, maupun alat tangkap dan juga berkaitan dengan pengadaan bekal selama penangkapan atau biaya operasional. Semua keperluan tersebut oleh si istri diperoleh dari warung terdekat yang biasanya sudah menjadi langganannya. (Anonim , 2008). Besarnya jumlah tanggungan keluarga juga merupakan faktor yang akan dipertimbangkan dan merupakan pendorong bagi istri dalam mengambil keputusan untuk bekerja yang menyangkut waktu, jenis dan harapan dalam pekerjaannya. Jumlah tanggungan dapat mencerminkan jumlah pengeluaran rumah tangga. Dengan demikian akan mendorong si istri untuk bekerja lebih giat dan hal ini akan memberikan sumbangan atau kontribusi pendapatan untuk keluarga. Dalam hal ini apabila jumlah tanggungan keluarga dalam kelompok besar atau banyak.

\section{Pemberdayaan Kaum Ibu Nelayan Diambil dari Harahap et.al}

Pengalaman menunjukan bahwa pemberdayaan wanita nelayan dalam pembangunan kelautan dan perikanan sulit dikembangkan, hal ini disebabkan karena kurangnya IPTEK dan kemiskinan yang selalu mengukung mereka (Anggita, 2012). Beberapa masalah dalam integrasi wanita nelayan dalam pembangunan kelautan dan perikanan antara lain, keadaan pendidikan yang umumnya sangat rendah, tenaga wanita sering tidak dinilai, masih adanya nilai-nilai sosial budaya masyarakat sebagai penghambat berperan sertanya wanita nelayan secara aktif, sedangkan beban kerja wanita dalam keluarga cukup tinggi.

Dalam rangka mengantisipasi keadaan tersebut di atas maka perlu diupayakan program Pemberdayaan wanita nelayan. Program ini pada hakekatnya diarahkan untuk mengembangkan dan mematangkan berbagai potensi yang ada pada diri mereka sehingga dapat terlibat dalam penyelenggaraan pembangunan perikanan secara sejajar dengan kaum prianya (Dinas Kelautan dan Perikanan, 2001). Salah satu cara pemberdayaan wanita nelayan ini adalah melalui jalur pendidikan dan pelatihan. Pendidikan di sini dapat berupa pendidikan formal melalui jalur sekolah untuk generasi muda nelayannya, selain itu melalui pendidikan non formal berupa penyuluhan atau pelatihan, juga melalui pendidikan informal berupa ceramah-ceramah di kalangan pengajian atau arisan, juga melalui percakapan-percakapan informal lainnya yang berupa informasi-informasi. Di sinilah peran wanita nelayan sangat penting di dalam menyampaikan informasi tentang pemanfaatan secara lestari sumber daya alam (SDA) kepada generasi mudanya (Soetrisno, 2001). 
Adapun program peranan wanita yang telah dan sedang dilaksanakan oleh pemerintah perlu ditingkatkan yaitu meliputi :

a. Latihan kepemimpinan wanita ditingkat pusat, propinsi dan kabupaten.

b. Latihan keterampilan di bidang usaha-usaha ekonomi produktif bagi para wanita.

c. Bantuan paket bahan serta peralatan kerja untuk mendorong upaya meningkatkan pendapatan keluarga.

d. Menyelenggarakan kelompok-kelompok kerja produktif dalam usaha mengembangkan kegiatan bersama (Soetrisno. 2001).

\section{Karakteristik Sosial Ekonomi Kaum Ibu Nelayan}

Diambil dari http://repository.usu.ac.id/bitstream/123456789/49701/4/Chapter\%20II.pdf

Berdasarkan hasil penelitian sebelumnya, adapun karakteristik sosial ekonomi istri nelayan yang dapat dijadikan acuan yaitu umur, tingkat pendidikan, jumlah tanggungan, dan pengalaman bekerja.

a. Umur

Sorenson (1964) menyatakan bahwa terdapat banyak bukti dimana perkembangan mental individu berjalan parallel dengan perkembangan fisik. Oleh sebab itu, dengan bertambahnya usia seseorang maka kemampuannya untuk memahami pengertianpengertian yang rumit akan meningkat, termasuk dalam mengelola pendapatannya (Suardiman, 2001). Umur bagi seorang wanita berperan dalam menghadapi kehidupan rumah tangganya. Semakin tinggi usia seseorang akan diikuti oleh kedewasaan dalam menghadapi suatu masalah. Semakin tinggi usia maka semakin mapan pula dalam memperoleh pendapatan. Dapat dikatakan bahwa umur berhubungan secara positif dengan pendapatan. Tetapi kemudian jika diikuti dengan menurunnya kemampuan maka umur berkorelasi negative terhadap pendapatan. Bila diasumsikan bahwa puncak umur pada kurva 45-50 tahun, maka ada hubungan positif antara umur (sampai 50 tahun) dengan pendapatan, sebaliknya ada hubungan yang negatif antara umur (diatas 50 tahun) dengan pendapatan. Jadi, pendapatan seseorang diduga meningkat sejalan bertambahnya usia sampai 45-50 tahun, namun sesudah usia itu diikuti oleh penurunan pendapatan (Suardiman, 2001).

b. Tingkat Pendidikan

Pendidikan merupakan sarana belajar dimana selanjutnya akan menanamkan pengertian sikap yang menguntungkan menuju pembangunan pertanian yang lebih modern. Mereka yang berpendidikan akan relatif cepat dalam melaksanakan adopsi. Begitu pula sebaliknya mereka yang berpendidikan rendah, akan sulit melaksanakan inovasi dengan cepat (Lubis, 2000).

c. Pendidikan akan memberikan kemampuan seseorang untuk berfikir rasional dan objektif dalam menghadapi masalah. Mereka yang berpendidikan diharapkan akan lebih tepat dalam menghadapi keputusan tentang apa yang harus mereka lakukan. Dengan demikian pendidikan berpengaruh positif terhadap pendapatan (Suardiman, 2001).

d. Jumlah Tanggungan

Semakin banyak anggota keluarga, maka akan semakin besar pula beban hidup yang akan ditanggung atau dipenuhi. Jumlah anggota keluarga akan mempengaruhi keputusan petani dalam berusaha (Soekartawi, 2003).

e. Pengalaman Bekerja

Pengalaman seseorang dalam bekerja berpengaruh dalam menerima inovasi dari luar. Bagi mereka yang mempunyai pengalaman usaha yang cukup lama akan lebih mudah menerapkan inovasi dari pemula (Soekartawi, 1999). 


\section{METODE}

Dalam proyek ini metode perancangan yang dipakai adalah meta-sintesis. Meta-sintesis juga termasuk penelitian yang menggunakan teknik kualitatif untuk merangkum hasil-hasil penelitian primer.

\section{Diambil dari: (http://eprints.umm.ac.id/38374/3/BAB\%20II.pdf) \\ Pengertian Meta-Sintesis}

Meta-sintesis yang juga di sebut sebagai systematic review merupakan suatu metode penelitian untuk melakakukan identifikasi, evaluasi dan interpretasi terhadap hasil penelitian yang sejenis untuk menjawab pertanyaan penelitian, topik tertentu atau fenomena yang sedang menjadi perhatian. Dari data-data sejenis tersebut akan diidentifikasi, dianalisis dan diinterpretasikan sehingga menghasilkan kesimpulan. Sedangkan secara definisi, Meta-sintesis diartikan sebagai teknik untuk melakukan penggabungan data yang ada untuk mendapatkan konsep baru atau pemahaman yang lebih mendalam. Hasil meta-sintesis yang didapatkan pada saat menganalisis beberapa penelitian primer, diharapkan dapat memunculkan pemahaman baru dan lebih memahamkan tentang suatu masalah diangkat.

\section{Tujuan Meta-Sintesis}

Telah dijelaskan dari pengertian yang di sampaikan bahwa Meta-sintesis dilakukan dengan menggabungkan data-data primer. Meta-sintesis memiliki tujuan yaitu untuk membantu menyimpulkan dari banyaknya informasi dari banyak penelitian yang terkadang saling bertentangan. Kemudian yang ke dua adalah meningkatkan kekuatan analisis, mengatasi ketidakpastian dan bisa untuk menjawab pertanyaan yang diajukan pada studi sebelumnya. Disimpulkan bahwa Meta-sintesis memiliki dua tujuan yaitu untuk menyimpulkan banyak informasi yang di dapatkan dalam hal ini skripsi pengembangan bahan ajar. Dan yang tujuan kedua adalah untuk meningkatkan kekuatan analisis yang dilakukan.

\section{Kelebihan Meta-sintesis}

Meta sintesis memiliki keunggulan atau kelebihan yang dapat diambil oleh peneliti. Berikut ini adalah kelebihan yang dimiliki oleh meta-analisis menurut Utomo:

a. Meta-sintesis menggunakan banyak sample, sehingga hasil yang di dapat representatif.

b. Menghasillkan suatu hasil yang signifikan.

c. Meta-sintesis dapat menjawab kesenjangan hasil yang terjadi dari studi yang beragam.

d. Lebih sedikit subjektivitas karena peneliti hanya meneliti dari data yang ada.

Kelebihan diatas menunjukkan bahwa meta-sintesis memiliki hasil yang beragam namun tetap signifikan serta meta-sintesis digunakan untuk menjawab hasil studi yang beragam, serta metasintesis dapat menghindari subjektivitas dalam penyimpulan hasilnya karena data yang di analisis menggunakan data yang ada.

\section{Keterbatasan Meta-Sintesis}

Selain mempunyai kelebihan, meta-sintsis mempunyai keterbatasan diantaranya berikut:

a. Sampling data: karena peneliti membutuhkan banyak data sehingga akan terjadi peneliti memiliki data yang tidak perlu di teliti.

b. Publikasi bias: peneliti hanya mempublikasikan hasil yang sesuai dengan tujuan peneliti saja.

c. Karena meta sintesis mengagretkan atau merata-ratakan, maka bisa terjadi sesuatu yang berbeda dianggap sama.

\section{Langkah-langkah Meta-Sintesis}

Meta sintesis mempunyai langkah-langkah yang yang tersusun secara urut. Dari beberapa literatur menyebutkan dan menjelaskan tentang langkahlangkah meta-sintesis yaitu dengan 
langkah pertama identifikasi pertanyaan peneliti atau memformulasikan pertanyaan peneliti; melakukan pencarian literasi; melakukan seleksi data berupa artikel, jurnal, maupun skripsi; melakukan analisis berupa statistik (jika menggunakan meta analisis) atau tidak dengan statistik (jika meta sintesis); memberikan kesimpulan dan menyusun laporan akhir. Berikut ini adalah langkah-langkah melakukan penelitian meta sintesis menurut Perry and Hammond dalam Siswanto (2010: 330) dalam http://eprints.umm.ac.id/38374/3/BAB\%20II.pdf:

a. Mengidentifikasi pertanyaan penelitian, hal ini dilakukan untuk mengetahui apa saja fokus permasalahan sehingga peneliti dan orang lain memahami apa yang akan di teliti.

b. Mengembangakan protokol penelitian meta sintesis, hal ini dilakukan untuk memberikan pedoman berupa literasi-literasi terkait meta sintesis maupun literasi mengenai hal yang akan di teliti.

c. Menentapkan lokasi data-data yang akan di analisis

d. Melakukan pemilihan data yang sesuai dengan masalah yang akan di analisis

e. Setelah semua data terkumpul, melakukan pemilihan kembali berdasarkan kualitas data yang cocok menjadi data penelitian

f. Melakukan analisis tiap data individu untuk mengetahui temuan pentingnya dengan menggunakan tabel analisis yang sudah di susun sesuai dengan literasi

g. Menarik kesimpulan dari data-data yang sudah di analisis

h. Penyajian hasil

\section{DISKUSI DAN HASIL}

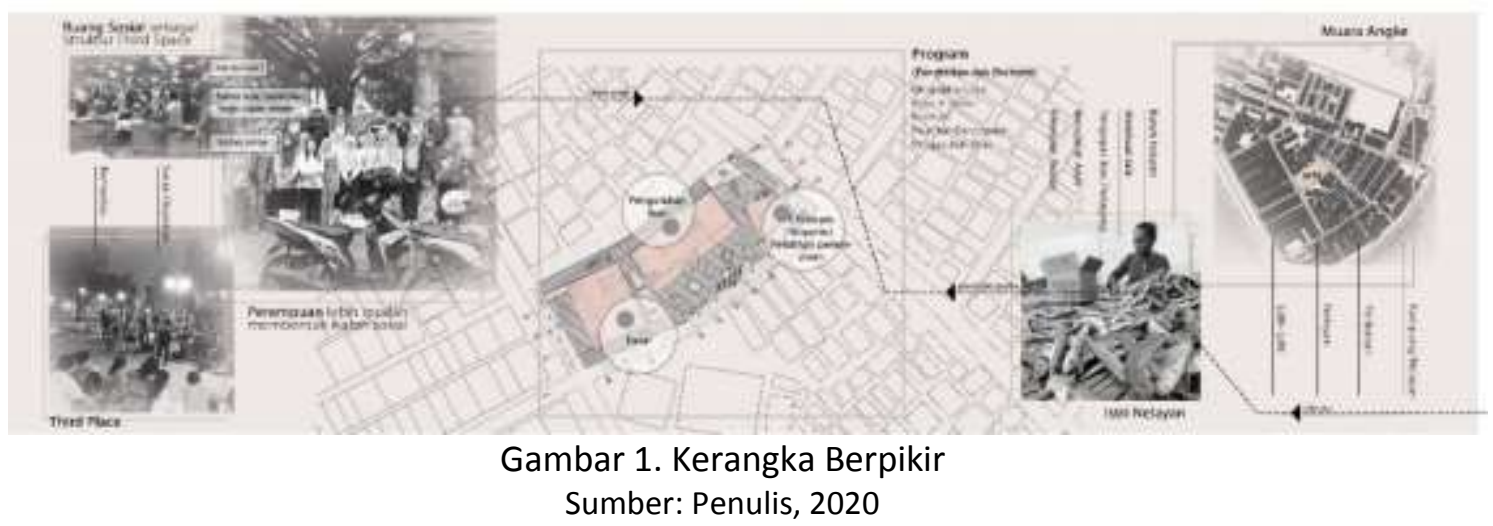

Setelah proses penjabaran dari ruang ketiga dan isu perempuan di Muara Angke ditemukannya keterkaitan satu sama lain, yaitu ruang sosial sebagai struktur ruang ketiga yang didalamnya diisi oleh kegiatan sosial dari beberapa organisasi sosial sehingga membentuk ikatan sosial. Ada beberapa faktor untuk masyarakat dapat berkumpul dan membentuk komunitas yaitu faktor umur, pekerjaan, jenis kelamin, dan gender. Pada faktor gender disebutkan bahwa perempuan lebih mudah untuk membentuk ikatan sosial dibanding laki-laki.

Dari kekuatan perempuan untuk membuat ikatan sosial dan peran kaum ibu yang sangat penting di Muara Angke serta didukung dari peraturan pemerintah bagian kelautan mengenai penyamarataan gender hal ini yang dijadikan dasar untuk membentuk program yang berada di dalam tapak dan disesuaikan dengan pekerjaan ganda dari kaum ibu atau istri nelayan Muara Angke. Fasilitas Pemberdayaan Masyarakat Nelayan dan Istri Nelayan kawasan Muara Angke menjadi program besar kegiatan pada proyek ini. Adapun program-program pendukung di dalamnya, yakni tempat pengolahan hasil laut, koperasi, dan pasar, disertai dengan program pendukung seperti tempat pelatihan perempuan dan tempat pengasuhan anak. 


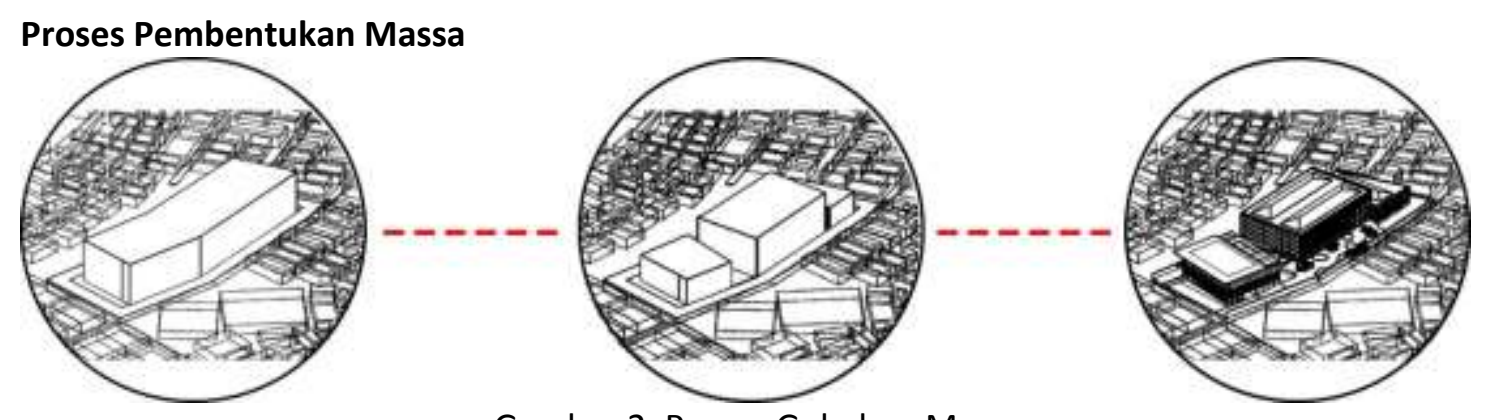

Gambar 2. Proses Gubahan Massa

Sumber: Penulis, 2020

Pada prosesnya massa dibagi menjadi 3 bagian untuk membedakan setiap fungsi yang ada dimulai dari sisi Timur yaitu pasar ikan lalu pengolahan ikan dan massa terakhir adalah tempay pengasuhan anak, koperasi, dan pelatihan perempuan. Massa dibagi menjadi 3 dikoneksikan hanya dari lantai satu dikarenakan adanya tempat pengolahan ikan yang berada di tengah tapak maka pemisahan ini dapat mengantisipasi bau dari tempat pengolahan ikan dan mempermudah area servis dari tempat pengolahan ikan.

\section{Sirkulasi dan Zoning Bangunan}

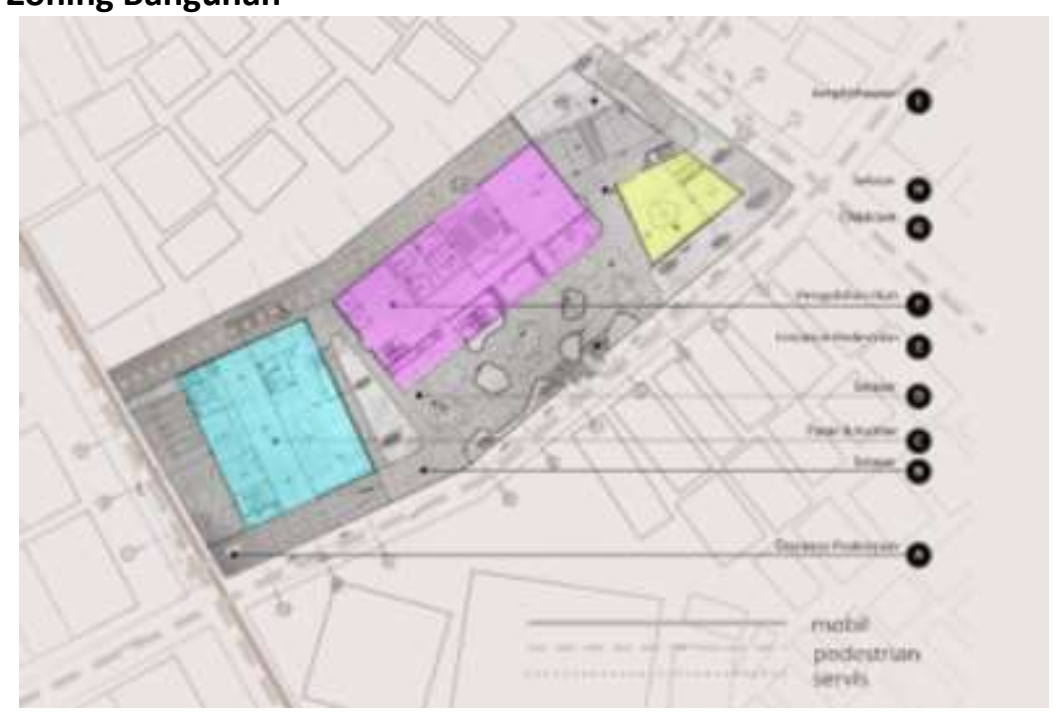

Gambar 3. Denah Sirkulasi dan Zoning

Sumber: Penulis, 2020

Sirkulasi pada bangunan dimulai dari A yang tertera pada gambar menyatakan bagian depan tapak. Dimana terdapat parkiran untuk kendaraan pribadi pada bagian depan tapak dan adanya entrance pedestrian pada sisinya untuk pengunjung pasar untuk masuk dan pekerja di pengolahan ikan. Sirkulasi servis berada di area utara pengolahan ikan (ungu). Adanya entrance di bagian Utara dan Barat tapak ditujukan kepada masyarakat sekitar tapak karena tapak dikelilingi oleh perumahan dan jalan yang tidak bisa dilewati oleh mobil.

Pada lantai 1 sirkulasi dari ketiga massa disatukan oleh komunal area di tengah sebagai titik temu dari ketiga fungsi tersebut. Lalu pengasuhan anak (kuning) berada di bagian Timur tapak bersinggungan langsung dengan komunal area yang berada di tengah agar akses ibu yang menitipkan anaknya mudah. Pada bagian pengolahan ikan untuk mempermudah proses pengolahannya lantai 1 digunakan sebagai area sortir. 


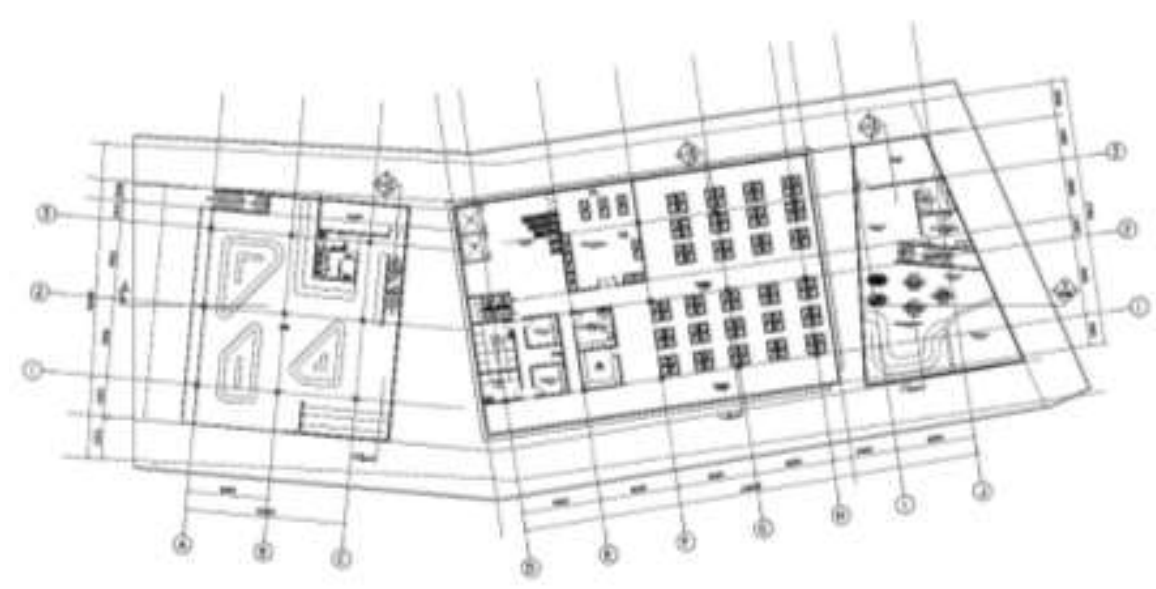

Gambar 4. Denah Lantai 2

Sumber: Penulis, 2020

Fungsi bangunan lantai 2 menerus dari lantai 1 bagian Timur adalah pasar ikan , bangian tengan pengolahan ikan setelah di sortir di lantai 1 proses pembersihan, pengupasan, pemilihan, dan pengelompokan berada disini. Hasil laut yang baik untuk dijual secara mentah bisa di teruskan ke pasar lalu bahan bahan yang akan dibekukan diteruskan ke lantai 3 lalu hasil laut yang bukan ikan dapat di proses dan dibekukan di lantai 4. Pada lantai 2 massa terakhir diisi oleh koperasi dan pelatihan perempuan, kedua program ini disatukan dikarenakan pengelolaan di titik beratkan terhadap perempuan sehingga membuat banyaknya interaksi sosial.
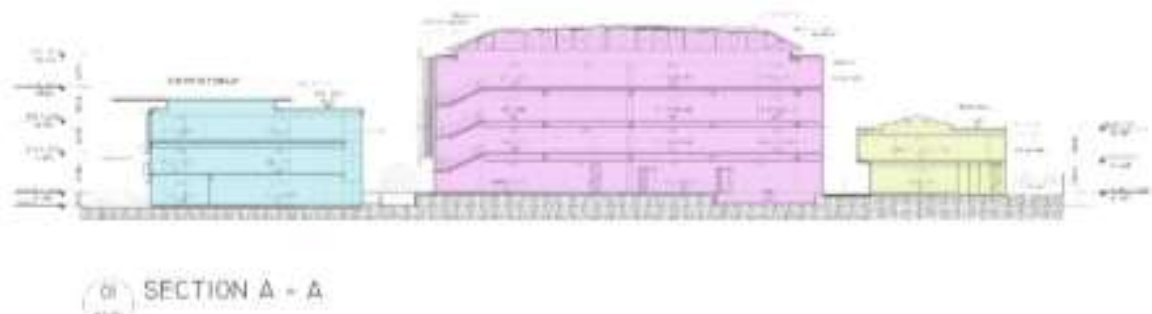

Gambar 5. Potongan A-A

Sumber: Penulis, 2020

Tampak

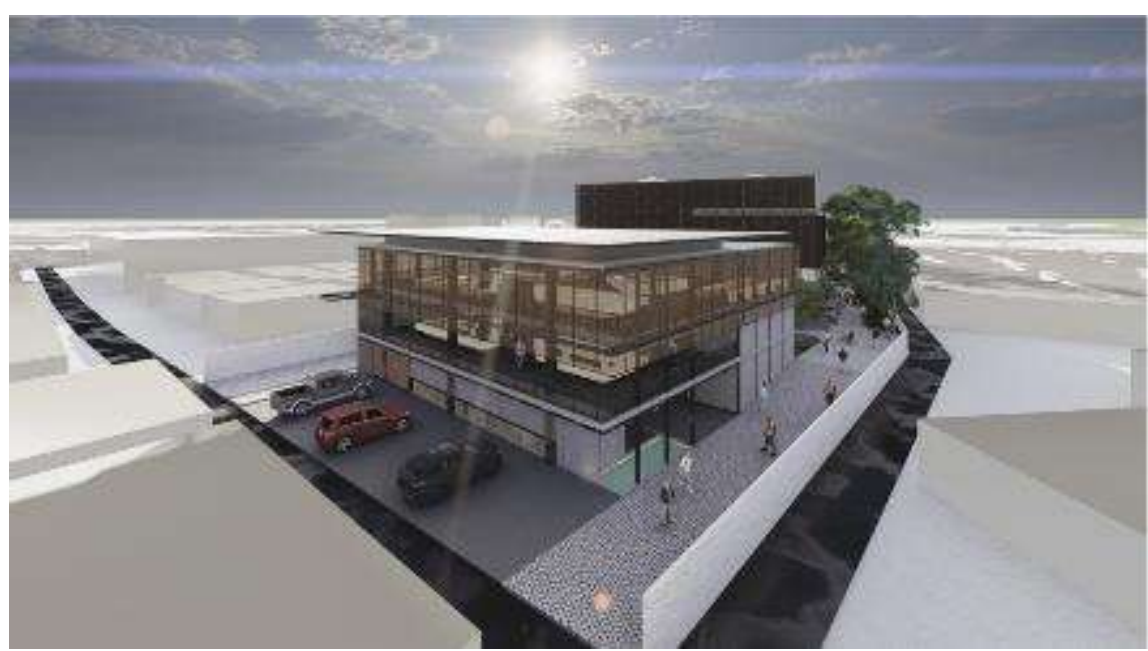

Gambar 6. Perspektif Bangunan 1

Sumber: Penulis, 2020 
Pada bagian tampak bangunan bahan yang digunakan untuk penutup adalah porforated steel dengan rangka baja berwarna hitam lalu dipadukan depan tembok-tembok finishing beton. Dengan karakteristik kawasan perkampungan dan perumahan pemilihan bahan dan bentuk diharapkan bisa menyatu dengan sekitar. Pada bagian pengolahan ikan tampak dipadukan dengan kayu dan bata serta plafond kayu pada komunal area lantai 1.

\section{Dimensi Bangunan}

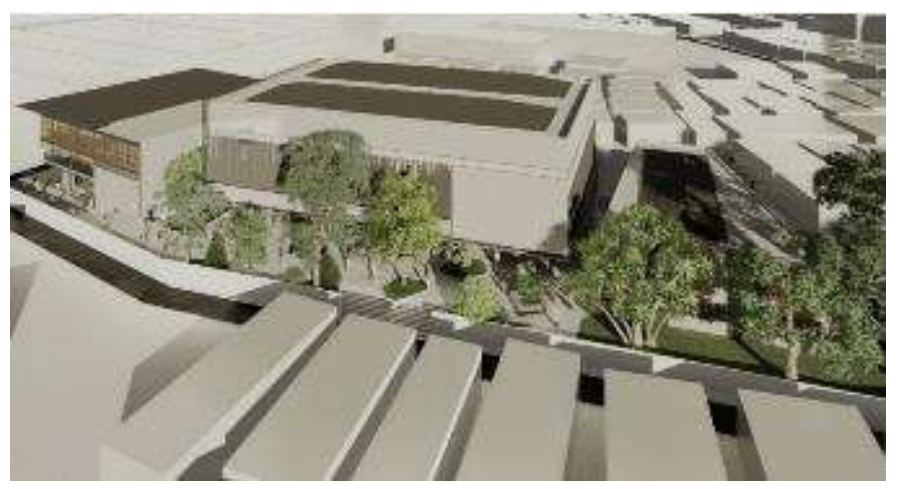

Gambar 7. Perspektif Bangunan 2

Sumber: Penulis, 2020

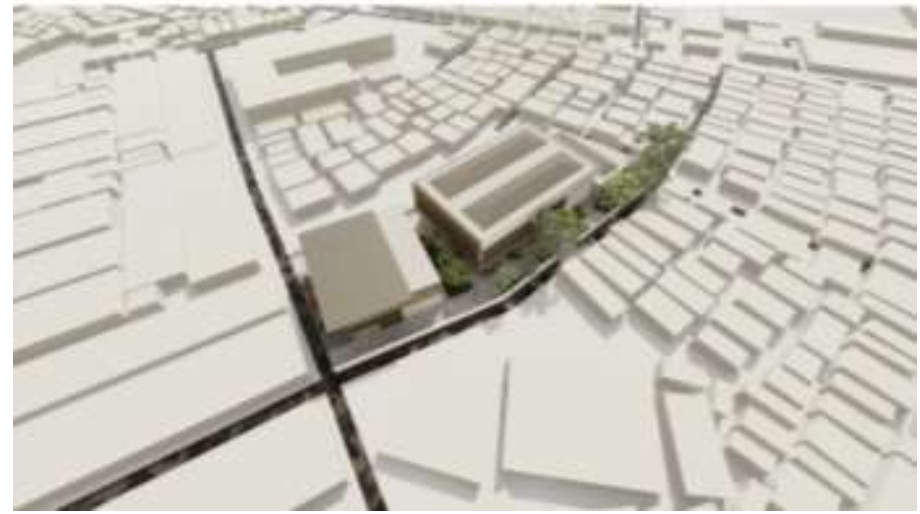

Gambar 8. Perspektif Bangunan 3

Sumber: Penulis, 2020

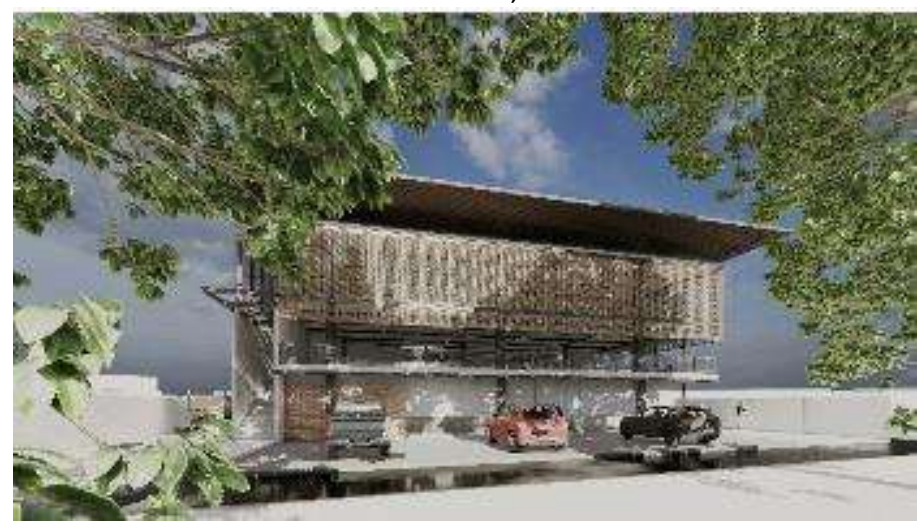

Gambar 9. Perspektif Bangunan 4

Sumber: Penulis, 2020

\section{KESIMPULAN DAN SARAN}

Dari hasil pembedahan Open Architecture as a Third Place dan investigasi kawasan Muara Angke ditemukan beberapa isu yang menyambungkan antar keduanya yaitu tentang perempuan. Dapat dilihat bahwa Muara Angke merupakan salah satu kampung nelayan yang sebagian masyarakat nelayannya terjebak dalam kapitalisme dari bos penyewa kapal hal ini 
menyebabkan sulit berkembangnya pekerja nelayan di Muara Angke.Adapun masalah tingkat pendidikan di Muara Angke terbilang rendah karena mayoritas hanya lulusan SD hal ini menambah kesulitan berkembangnya masyarakat Muara Angke khususnya nelayan. Masalah tersebut menajdikan masyarakat nelayan Muara Angke harus bekerja lebih ekstra untuk menafkahi keluarganya sehingga adanya peran istri nelayan untuk membantu suaminya untuk mencari nafkah. Istri nelayan memegang peranan penting dalam kelangsungan hidup masyarakat nelayan, bukan hanya harus melakukan pekerjaan rumah dan mengurus anak mereka juga harus membantu suaminya dari persiapan untuk bernelayan(membuat jalan), setelah bernelayan (mengupas kerang, mengasinkan ikan, mengupas udang, dll), serta mengurus finansial keluarganya juga (menjual hasil laut dan lain lain). Dengan adanya ruang pemberdayaan kaum ibu Muara Angke diharapkan dapat mewadahi kegiatan kaum ibu Muara Angke dalam mengurus keluarganya lebih maksimal .

\section{REFERENSI}

Harahap, A., dkk. (2012). PERANAN ISTRI NELAYAN TERHADAP PENDAPATAN KELUARGA (Kasus : Desa Bagan Serdang, Kecamatan Pantai Labu, Kabupaten Deli Serdang). https://media.neliti.com/media/publications/15124-ID-peranan-istri-nelayan-terhadappendapatan-keluarga-kasus-desa-bagan-serdang-keca.pdf

Oldenburg, R. (1997). The Great Good Place. Cambridge: Da Capo Press

Oldenburg, R. (2001). Celebrating the Third Place: Inspiring Stories About the "Great Good Place" at the Heart of Our Communities. New York: Marlowe \& Company.

Putri, D.P.K., Lestari, S. (2015). Pembagian Peran Dalam Rumah Tangga pada Pasangan Suami Istri Jawa. Jurnal Penelitian Humaniora, 16(1), 72-85

Robin, et.al. (2018). Analisis Mekanisme Adaptif Dan Kerentanan Nafkah Nelayan di Teluk Jakarta (Studi Kasus: Nelayan Muara Angke, Kamal Muara dan Kalibaru). Sodality: Jurnal Sosiologi Pedesaan, 6(3), 212-219

(2013). Kerangka Pikir Meta-Sintesis Pengembangan Bahan Ajar Mahasiswa UMM tahun

2013-2017. http://eprints.umm.ac.id/38374/3/BAB\%20ll.pdf http://repository.usu.ac.id/bitstream/123456789/49701/4/Chapter\%20Il.pdf 
